\title{
UMA ABORDAGEM COMPARADA ACERCA DO DISCURSO DE ÓDIO ENTRE BRASIL E ESTADOS UNIDOS
}

\author{
A COMPARATIVE APPROACH TO HATE SPEECH BETWEEN BRAZIL AND THE \\ UNITED STATES
}

\author{
UN ABORDAJE COMPARADO SOBRE EL DISCURSO DE ODIO EN BRASIL Y \\ ESTADOS UNIDOS
}

\author{
Miguel Tedesco WedY \\ https://orcid.org/0000-0002-9227-8573 / http://lattes.cnpq.br/2582264833323481 / wedymiguel2@gmail.com \\ Universidade do Vale do Rio dos Sinos - UNISINOS. \\ São Leopoldo, Rs, Brasil. \\ LENON OLIVEIRA HORBACH \\ https://orcid.org/0000-0002-1277-9408 / http://lattes.cnpq.br/9092655313964385 / lenonhorbach@gmail.com \\ Universidade do Vale do Rio dos Sinos - UNISINOS \\ São Leopoldo, RS, Brasil
}

\begin{abstract}
RESUMO
A proposta do presente estudo é analisar, por meio de uma perspectiva comparada, a possibilidade de censura quando evidenciado discurso de ódio, problematizando quais fundamentos que caracterizam a censura e consequente relativização do direito à liberdade de expressão em face de discursos vexatórios. Demonstra-se a relevância do direito de liberdade de expressão no constitucionalismo brasileiro e americano, contrapondo a postura liberal norteamericana à do Estado brasileiro, que utiliza da censura como tentativa de propagação da igualdade. Como método de abordagem, aplica-se o dedutivo, partindo de uma perspectiva jurídico-constitucional nacional e internacional, para posterior aplicação dos conhecimentos em casos concretos. Em linhas gerais, mesmo que uma opinião carregue ódio, não há base suficiente para censura, sugere-se a responsabilização a posteriori, repelindo-se o cerceamento da liberdade de pensamento, ainda que a opinião seja intolerante.
\end{abstract}

Palavras-chave: Censura; Discurso de ódio; Liberdade de expressão; Primeira emenda.

\section{ABSTRACT}

The purpose of this study is to analyse, through a comparative perspective, the possibility of censorship when evidenced hate speech, problematizing the fundamentals that characterize censorship and the consequent relativization of the expression freedom rights on vexing speechs. For this the relevance of expression freedom rights in Brazilian and American constitutionalism was demonstrated, from the liberal position of the American State, to the counterpart of the Brazilian State in using censorship as a way of propagating the right of equality. The deductive method was applied, starting from a juridical-national and international perspective, for later application of the knowing in concrete cases. Broadly speaking, even if any opinion carries hate, there is not enough basis for censorship, suggesting, a posteriori responsibility, repelling the repression of thought freedom, even if the opinion is intolerant.

Keywords: Censure; Hate speech; Freedom of expression; First amendment. 


\section{RESUMEN}

La propuesta del presente estudio es analizar, a través de una perspectiva comparada, la posibilidad de censura cuando se evidencian discursos de odio, problematizando cuáles fundamentos que caracterizan la censura, y consecuente relativización del derecho a la libertad de expresión frente a discursos vejatorios. Se demostró la relevancia del derecho de libertad de expresión en el constitucionalismo brasileño y americano, desde la postura liberal americana, en contrapartida a la del Estado brasileño en usar la censura como intento de propagación de la igualdad. Como método se aplicó el deductivo, partiendo de una perspectiva jurídico-constitucional nacional e internacional, para posterior aplicación de los conocimientos en casos concretos. En líneas generales, aunque una opinión cargue odio, no hay base suficiente para censurar, sugiriéndose, la responsabilidad a posteriori, repeliendo el cercenamiento de la libertad de pensamiento, aunque la opinión sea intolerante.

Palabras clave: Censura; Discurso de odio; La libertad de expresión; Primera enmienda.

\section{SUMÁRIO}

INTRODUÇAO; 1 DA LIBERDADE DE EXPRESSÃO AO DISCURSO DE ÓDIO; 2 DA VEDAÇÃO À CENSURA: A VISÃO LIBERAL ESTADUNIDENSE; 3. A LIBERDADE DE EXPRESSÃO NO BRASIL: A NECESSIDADE DE DIMINUIÇÃO DAS DESIGUALDADES SOCIAIS; CONCLUSÃO; REFERÊNCIAS.

\section{INTRODUÇÃO}

Por mais que seja um tema em voga, aparentemente rediscutir liberdade de pensamento remete à velha dicotomia entre liberdade de expressão versus os direitos de personalidade, trazida pelo próprio texto constitucional no artigo $5^{\circ}$ da Constituição Federal Brasileira. Entretanto, quando se discute a temática envolvendo discurso de ódio, liberdade de expressão e censura, outros princípios devem ser devidamente considerados, como a igualdade e a dignidade da pessoa humana.

O problema central da presente pesquisa se molda em evidenciar quais são os fundamentos que caracterizam a possibilidade de censura e a consequente relativização do direito à liberdade de expressão em face de discursos de ódio. Dessa forma, o objetivo do artigo é analisar a possibilidade, ou não, de censura no sistema constitucional brasileiro, quando evidenciada a ocorrência de discurso de ódio, como forma de limitação à liberdade de expressão, a partir de uma perspectiva comparada com os Estados Unidos da América.

Para tanto, será aplicado o método dedutivo de abordagem, uma vez que este se mostra mais adequado ao fim da pesquisa, partindo-se de uma perspectiva jurídico-constitucional nacional e internacional, para posteriormente aplicar os conhecimentos a casos concretos. Ainda, a técnica de pesquisa é bibliográfica a partir de documentação indireta em fontes primárias, tais como legislação nacional e internacional, jurisprudência, e documentos em geral, 
ISSN 1981-3694

(DOI): 10.5902/1981369430692

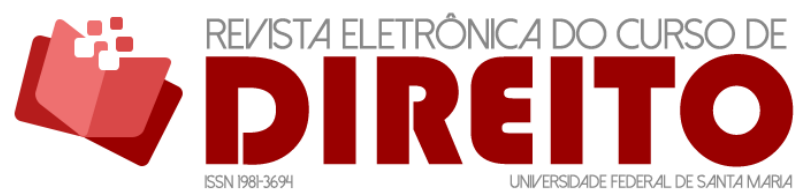

UMA ABORDAGEM COMPARADA ACERCA DO DISCURSO DE ÓDIO ENTRE BRASIL E ESTADOS UNIDOS

MIGUEL TEDESCO WEDY LENON OLIVEIRA HORBACH

bem como em fontes secundárias bibliográficas, nomeadamente em livros, periódicos científicos, e na rede de internet.

Neste ínterim, inicialmente se demonstra a relevância e a importância do direito à liberdade de expressão, tanto no contexto brasileiro, quanto no norte-americano, uma vez que, nas duas Constituições, esse direito é colocado em lugar de destaque e a história que reflete a cultura dos dois países é permeada pela luta por liberdade. A discussão, todavia, se coloca frente à insistência do Estado brasileiro em vedar discursos de ódio, deixando de tutelá-los, e dessa forma, muitas das vezes, incidindo em censura.

Paralelamente se evidencia, por meio de precedentes e da doutrina norte-americana, que há possibilidade de tutela para discursos de ódio, desdobrando-se sobre o direito de liberdade de expressão, não sucedendo em censura. Ainda, fundamenta-se essa perspectiva através de autores como Cass Sunstein, Ronald Dworkin, e Stuart Mill, sintetizando que, mesmo em não sendo absoluto o direito de liberdade de expressão, esse só deve ser restringido ou censurado quando comprovado o dano. Conforme as lições de Mill contra a censura, em sua obra "on liberty", na forma que, aparentemente, discursos de ódio, ou hate speech, como trabalhado na doutrina americana, não seriam vedados com base em possíveis danos.

Ao contrário, no sistema brasileiro, grande parte da doutrina constitucionalista que escreve precisamente sobre discurso de ódio, considera que há grande disparidade e injustiça na sociedade, que reproduz intolerância e preconceito diariamente. Dessa forma, tutelar o discurso de ódio fomentaria a desigualdade social no país, o que contraria os objetivos da República Federativa do Brasil.

Com o intuito de demostrar com maior nitidez a posição de cada país para com o tema, analisa-se o caso "Skokie vs national socialist party of américa", julgado pela Suprema Corte dos Estados Unidos, e o caso "Siegfried Ellwanger Castan", julgado pelo Supremo Tribunal Federal, através do HC n. 82.424-2/RS. Ainda, de forma breve e precisa, evidencia-se o entendimento de alguns juízes estadounidenses que colocam a liberdade de expressão em posição de superioridade com relação a outros direitos, através dos casos "Dep't of Chicago vs Mosley" e “Abrams vs United States”.

\section{DA LIBERDADE DE EXPRESSÃO AO DISCURSO DE ÓDIO}

Pouco antes da Constituição democrática de 1988, discutia-se com menor frequência a problemática envolvendo o limite ao direito fundamental de liberdade expressão, uma vez que 
ISSN 1981-3694

(DOI): 10.5902/1981369430692

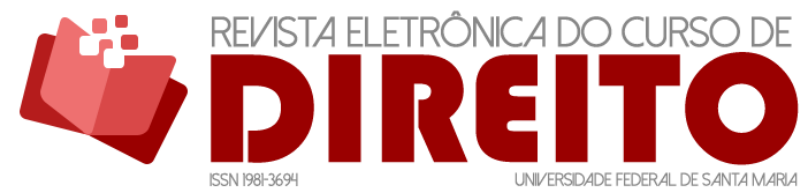

UMA ABORDAGEM COMPARADA ACERCA DO DISCURSO DE ÓDIO ENTRE BRASIL E ESTADOS UNIDOS

MIGUEL TEDESCO WEDY LENON OLIVEIRA HORBACH

"no tempo da ditadura militar, a censura recaía quase sempre sobre manifestações expressivas que o governo considerava perigosas ou ofensivas aos seus próprios interesses". ${ }^{1}$

Durante a Ditadura Militar, a censura era a regra e, por isso, não se discutiam os limites da liberdade de expressão. Baseando-se na ideia de combate ao comunismo, a restrição à expressão estava totalmente institucionalizada, ${ }^{2}$ sendo o meio pelo qual o governo controlava o que poderia ser dito, publicado e transmitido pelos meios de comunicação. ${ }^{3}$

Com a democratização de 1988 (CF/88), um novo cenário trouxe complexas questões envolvendo o direito de liberdade de expressão, fortemente protegido pela Carta Magna, assim como outros direitos, em que se encontram a privacidade, a igualdade, a honra, a imagem, a presunção de inocência. ${ }^{4}$ Apesar dessa tutela constitucional, o exercício da liberdade de expressão não é absoluto. Com o tempo, percebeu-se que a liberdade de expressão, tal como qualquer direito, poderia ser usada de forma abusiva, trazendo danos graves à sociedade como um todo, mormente nos tempos atuais, com o desenvolvimento sem par das redes sociais.

Logo após a conquista da liberdade exacerbada de expressão, alguns setores da sociedade acabaram sendo atingidos por discursos carregados de ódio, que "tendem a provocar uma babel de sentimentos negativos nas suas vítimas". ${ }^{5} \mathrm{O}$ discurso de ódio, segundo David Brink, "utiliza epítetos para insultar e estigmatizar terceiros com base em raça, gênero, orientação sexual, ou formas de associação". ${ }^{6}$ Por mais que o direito à liberdade de expressão apareça como uma das maiores conquistas obtidas pela sociedade organizada, como dito anteriormente, nada impede que se encontrem limites ao exercício desse direito em prol de outros. ${ }^{7}$

Discursos de ódio são expressões de atitude discriminatória, severamente ofensivas, que têm o condão de gerar segregação social. Dessa forma, Brink afirma que debates em que

\footnotetext{
1 SARMENTO, Daniel. LIVRES E IGUAIS: Estudos de Direito Constitucional. Rio de Janeiro: Lumen Juris, 2006. p. 207.

${ }^{2}$ CARVALHO, Lucas Borges de. Censura e Liberdade de Expressão no Brasil. Rio de Janeiro: Lumen Juris, 2016. p. 23.

${ }^{3}$ CARVALHO, Lucas Borges de. Censura e Liberdade de Expressão no Brasil. Rio de Janeiro: Lumen Juris, 2016. p. 25

${ }^{4}$ SARMENTO, Daniel. LIVRES E IGUAIS: Estudos de Direito Constitucional. Rio de Janeiro: Lumen Juris, 2006. p. 208.

${ }^{5}$ SARMENTO, Daniel. LIVRES E IGUAIS: Estudos de Direito Constitucional. Rio de Janeiro: Lumen Juris, 2006. p. 246

${ }^{6}$ BRINK, Davi O. In: SAMPAIO, José Adércio Leite (Coord.). Liberdade de expressão no século XXI. Belo Horizonte: Del Rey, 2016. p. 27.

7 BARROS, Caroline Maria Costa. A moral como instrumento limitador da liberdade de expressão: apontamentos sobre o exercício (i) legítimo do discurso de ódio. Rio de Janeiro: Lumen Juris, 2015. p. 105.
} 
ISSN 1981-3694

(DOI): $10.5902 / 1981369430692$

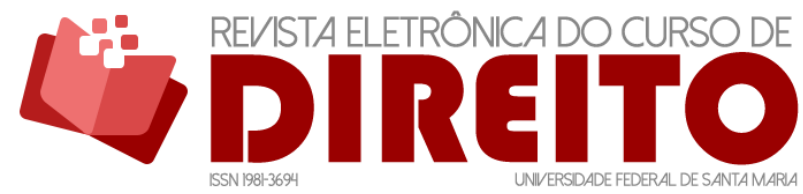

UMA ABORDAGEM COMPARADA ACERCA DO DISCURSO DE ÓDIO ENTRE BRASIL E ESTADOS UNIDOS

MigueL TEDESCO WEDY LENON OLIVEIRA HORBACH

aparecem discurso de ódio "parecem forçar uma escolha entre igualdade ou liberdade", 8 onde os interesses igualitários exigem restrições à liberdade de expressão frente ao discurso de ódio. Todavia, interesses libertários concordam que "a cura parece tão maléfica quanto à doença". 9

Reforçando a ideia de limitação do direito de liberdade de expressão frente a discurso de ódio, Gilmar Mendes salienta que se deve pôr em prática a liberdade e a igualdade, mas sobretudo a fraternidade, uma vez que esse princípio é essencial em uma sociedade complexa e multicultural, cenário em que todas as formas de fundamentalismo, racismo, segregação social ou racial representam verdadeira afronta aos direitos humanos. ${ }^{10}$ Nesse mesmo sentido, Sarmento acrescenta que a repetição de certas afirmações afeta a percepção que a maioria tem de grupos já estigmatizados, reforçando estereótipos negativos e incitando a discriminação, como por exemplo. ${ }^{11}$ Touriño, quando se refere à liberdade de expressão, contempla não se tratar de um direito absoluto, inclusive por encontrar limite, como qualquer outro direito fundamental, nos direitos dos demais, inserindo a ideia de que nossos direitos acabam onde começam os dos outros. ${ }^{12}$

Assim, percebe-se que há sustentação doutrinária no sentido de que o direito de se expressar não é absoluto, mas está condicionado a uma regulação. ${ }^{13}$ Aliás, a regulação estatal do direito de liberdade de expressão encontra amparo no próprio texto constitucional, que não

${ }^{8}$ Gilmar Mendes observa: Quanto aos valores liberdade e igualdade, o Ministro salienta que essa dualidade é base de um Estado constitucional, sendo que até mesmo a história do constitucionalismo se confunde com a história dos dois fundamentos frente a ordem jurídica, não podendo negar-se a simbiose entre liberdade e igualdade no Estado democrático de direito. MENDES, Gilmar. A Jurisdição constitucional no Brasil e seu significado para a liberdade e a igualdade. Disponível em: http://www.stf.jus.br/arquivo/cms/noticiaartigodiscurso/anexo/munster_port.pdf. Acessado em 3 ago. 2017.

9 BRINK, Davi O. Princípios de Millian, liberdade de expressão e discurso de ódio. In: SAMPAIO, José Adércio Leite (Coord.). Liberdade de expressão no século XXI. Belo Horizonte: Del Rey, 2016. p. 28.

10 MENDES, Gilmar. A Jurisdição constitucional no Brasil e seu significado para a liberdade e a igualdade. Disponível em http://www.stf.jus.br/arquivo/cms/noticiaartigodiscurso/anexo/munster_port.pdf. Acessado em 3 ago. 2017.

11 SARMENTO, Daniel. LIVRES E IGUAIS: Estudos de Direito Constitucional. Rio de Janeiro: Lumen Juris, 2006. p. 246/247.

12 TOURIÑO, Alejandro. El derecho al olvido y a la personalidade en internet. Madrid: Catarata, 2014. p. 319.

13 SAGÜES, Nestor Pedro. Censura judicial previa a la prensa: posición de la Corte Interamericana de Derechos Humanos. Anuario de Derecho Constitucional Latinoamericano, Montevideo, ano 12, t. II, p. 965 977, 2006. 
ISSN 1981-3694

(DOI): $10.5902 / 1981369430692$

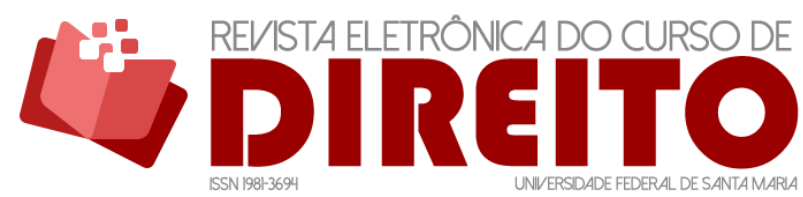

UMA ABORDAGEM COMPARADA ACERCA DO DISCURSO DE ÓDIO ENTRE BRASIL E ESTADOS UNIDOS

Miguel TEDESCO WeDY LENON OLIVEIRA HORBACH

admite direitos absolutos, assim sendo aqueles que não sejam passíveis de análise ou restrição por parte do Poder judiciário ou legislativo. ${ }^{14}$

A restrição judiciária ao direito de liberdade de expressão pode se dar de forma concreta, através de decisões judiciais, e de forma abstrata, quando parte do poder legislativo, em razão de lei. Seria, assim, imprescindível a intervenção estatal para a regulação do direito de liberdade de expressão, salvaguardando os princípios de dignidade, honra e igualdade, frente a discursos carregados de ódio. ${ }^{15}$

A partir deste cenário já delineado, ao que parece, quanto mais se intensificam os discursos de ódio, mais ênfase se dá à possibilidade de censura desses discursos. Tende a calhar a constatação de Owen Fiss de que "algumas vezes nós devemos reduzir as vozes de alguns para podermos ouvir as vozes de outros". ${ }^{16}$

Considerando que discursos carregados de ódio têm como escopo desprezar determinados setores sociais, geralmente grupos de minorias, podendo ocasionar a impossibilidade de participação no meio social, adverte-se de que tais discursos devem ser combatidos, ${ }^{17}$ abrindo espaço para, além da responsabilização civil, a vedação prévia de discursos intolerantes. ${ }^{18}$

Em um outro sentido, o jurista inglês William Blackstone através de uma matriz americana de liberdade de expressão, concordava com a responsabilização civil por discursos de ódio, reiterando que o Estado não pode impedir que os cidadãos expressem o que bem entendem. Contudo, pode puni-los pela expressão, caso essa for "afrontosa ou perigosa". ${ }^{19}$

Já observando o direito alemão, Brugger acrescenta que "a liberdade de expressão de maneira nenhuma tem sempre precedência sobre a proteção da personalidade”. ${ }^{20}$ Por seu turno,

\footnotetext{
${ }_{14}$ PINTO, Indiara Liz Fazolo. Liberdade de expressão, Lei de Imprensa e discurso de ódio - Da restrição como violação à limitação como proteção. A\&C - R. de Dir. Administrativo \& Constitucional | Belo Horizonte, ano 13, n. 53, p. 195-229, jul./set. 2013. p. 209.

15 PINTO, Indiara Liz Fazolo. Liberdade de expressão, Lei de Imprensa e discurso de ódio - Da restrição como violação à limitação como proteção. A\&C - R. de Dir. Administrativo \& Constitucional | Belo Horizonte, ano 13, n. 53, p. 195-229, jul./set. 2013. p. 212.

${ }^{16} \mathrm{FISS}$, Owen M. A ironia da liberdade de expressão: Estado, regulação e diversidade na esfera pública. 1. ed. Rio de Janeiro: Renovar, 2005. p. 49.

17 MEYER-PFLUG, Samantha Ribeiro. Liberdade de Expressão e discurso do ódio. São Paulo: Editora Revista dos Tribunais, 2009. p. 110.

${ }^{18}$ BELLUSCIO, Augusto César. Censura judicial previa a la prensa: posición de la Corte Interamericana de Derechos Humanos. Anuario de Derecho Constitucional Latinoamericano, Montevideo, ano 12, t. II, p. 949 963, 2006.

19 DWORKIN, Ronald. 0 direito da liberdade: a leitura moral da Constituição norte-americana. Tradução Marcelo Brandão Cipolla. São Paulo: Martins Fontes, 2006. p. 314.

${ }^{20}$ BRUGGER, Wienfried. Proibição ou proteção do discurso de ódio? Algumas observações sobre o direito alemão e o americano. Revista de Direito Público, Brasília, v. 1, n. 15, p. 117-136, jan./mar.2007. p. 122.
} 
ISSN 1981-3694

(DOI): $10.5902 / 1981369430692$

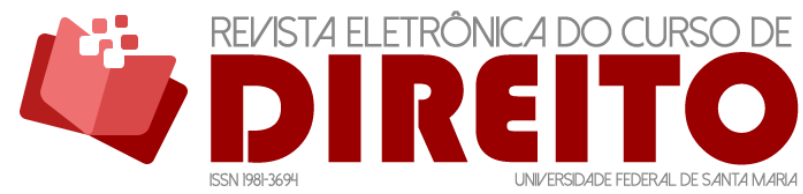

UMA ABORDAGEM COMPARADA ACERCA DO DISCURSO DE ÓDIO ENTRE BRASIL E ESTADOS UNIDOS

Miguel TEDESCO WedY LENON OLIVEIRA HORBACH

Kant conceituava o direito como "uma justa restrição à liberdade de cada um para que todas as liberdades coexistam", ${ }^{21}$ ou seja, na sociedade não deveria haver liberdade em excesso.

A própria filosofia liberal previa a necessidade de limitação da liberdade de expressão quando em dicotomia com outros direitos e valores, onde:

Relendo Lucke e Montesquieu não se encontra nenhum traço de hostilidade ao Estado nem qualquer veneração a uma esfera privada não regulada. Conhecedores do caos e da anarquia que significava a opressão privada, o domínio dos fortes sobre os fracos, corrente nos séculos XVII e XVIII, eles não se opunham à autoridade em geral, mas apenas a autoridade arbitrária e injusta. Assim, a liberdade apreciada por esses autores é seriamente distorcida quando descrita exclusivamente como negativa. ${ }^{22}$

Com efeito, a garantia constitucional de expressão subjaz a ideia de responsabilização, ou nas palavras de Farias "não se vê liberdade sem a correspondente responsabilidade, sendo inerente à função de comunicar a responsabilidade"23. Ou nas palavras de Jabur em "nenhum momento da história moderna a liberdade de expressar-se e comunicar-se veio assegurada sem o correlato contrapeso". ${ }^{24}$

Igualmente, o processo de globalização tem requerido do sistema jurídico uma proteção contra o mau uso das redes de comunicação, principalmente após o advento da internet. ${ }^{25}$ Percebe-se que além da responsabilização pelo uso incorreto do direito à liberdade de expressão, fomenta-se um sistema social, político e jurídico que possibilite com maior amplitude o controle estatal, reiterando-se a ideia de, não apenas admitir a posterior responsabilização, mas também a restrição prévia, abrindo no sistema constitucional brasileiro exceção à vedação à censura.

Brink, entretanto, reforça a tese de que ideias ofensivas, carregadas de ódio, são parte do preço pago para que o direito constitucional de liberdade de expressão seja protegido. Para o autor, uma resposta correta ao discurso de ódio é maior liberdade de expressão, presumindo que o igualitarismo condena o discurso de ódio, não restringindo a liberdade, dirigindo-se totalmente

\footnotetext{
${ }^{21}$ KANT apud FARIAS, Edilson. Liberdade de Expressão e Comunicação: teoria e proteção constitucional. São Paulo: Editora Revista dos Tribunais, 2004. p. 243.

22 HOLMES, Stephen. Liberal constraints on private power? Reflections on the origins and rationale of acess regulation. In: LICHTENBERG, Judith. Democracy and mass media. Nova York: Cambridge University Press. 1995. p. 21-65.

${ }^{23}$ FARIAS, Edilson. Liberdade de Expressão e Comunicação: teoria e proteção constitucional. São Paulo: Editora Revista dos Tribunais, 2004. p. 245.

24 JABUR, Gilberto Haddad. Liberdade de pensamento e direito à vida privada: conflitos entre direitos da personalidade. São Paulo: Editora Revista dos Tribunais, 2000. p. 245.

${ }^{25}$ FARIAS, Edilson. Liberdade de Expressão e Comunicação: teoria e proteção constitucional. São Paulo: Editora Revista dos Tribunais, 2004. p. 245.
} 
ISSN 1981-3694

(DOI): $10.5902 / 1981369430692$

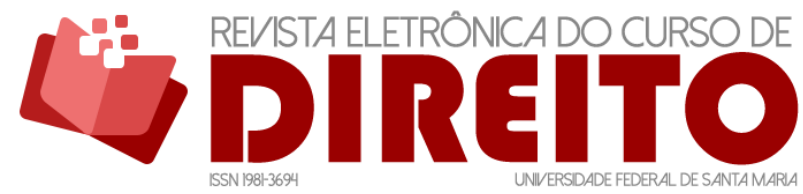

UMA ABORDAGEM COMPARADA ACERCA DO DISCURSO DE ÓDIO ENTRE BRASIL E ESTADOS UNIDOS

MIGUEL TEDESCO WEDY LENON OLIVEIRA HORBACH

contra a ideia de censura. ${ }^{26}$ Butler concorda, acrescentando que "a cadeia ritual do discurso do ódio não pode ser refutada de maneira efetiva por meio da censura", uma vez que a censura se mostra como uma resposta muito simples para o discurso e a lei, que são bastante complexos. ${ }^{27}$

Referindo-se as decisões da Suprema Corte Americana, Dworkin entende que é importantíssimo que a Corte continue protegendo todas as formas de expressão, até aqueles discursos de odiamos, para se dar base a uma "sociedade liberal comprometida com a responsabilidade moral individual”, onde nenhuma censura de conteúdo seja compatível com esse compromisso. ${ }^{28}$

\section{DA VEDAÇÃO À CENSURA: A VISÃO LIBERAL ESTADUNIDENSE}

$\mathrm{Na}$ contramão do que fora apresentado, David Brink posiciona-se contra a censura mesmo em casos de flagrantes discursos de ódio, fundamentada no pensando clássico de John Stuart Mill. Mill, em sua obra On Liberty, traz quatro razões para se resguardar o direito à liberdade de expressão, opondo-se à censura, mesmo em situações de identificam-se discursos de ódio.

A primeira razão para não censurar discursos é que uma opinião censurada tem a possibilidade de ser verdadeira. Nas palavras de Mill "se uma opinião é compelida ao silêncio, é possível que ela seja verdadeira, em virtude de algo que podemos vir a conhecer com certeza". O autor acredita que negar essa premissa é "presumir a nossa infantilidade". ${ }^{29}$

Mesmo que literalmente falsa, a segunda razão de Mill contra a censura é de que uma opinião pode conter verdades:

Mesmo que a opinião que a que se impôs silencia seja um erro, pode conter, e muito comumente contém, uma parte de verdade. $E$, uma vez que a opinião geral ou dominante sobre um assunto é raramente, ou nunca, a verdade inteira, só pela colisão das opiniões contrárias se faz provável se complete a verdade com a parte ausente. ${ }^{30}$

\footnotetext{
${ }^{26}$ BRINK, Davi O. Princípios de Millian, liberdade de expressão e discurso de ódio. In: SAMPAIO, José Adércio Leite (Coord.). Liberdade de expressão no século XXI. Belo Horizonte: Del Rey, 2016. p. 28.

${ }^{27}$ BUTLER, Judith. Excitable Speech. A Politics of the Performative. New York: Routledge, 2000.

${ }^{28}$ DWORKIN, Ronald. 0 direito da liberdade: a leitura moral da Constituição norte-americana. Tradução Marcelo Brandão Cipolla. São Paulo: Martins Fontes, 2006. p. 237.

${ }^{29}$ MILL, John Stuart. Sobre a liberdade. Tradução Alberto da Rocha Barros. 2. ed. Rio de Janeiro: Vozes, 1991. p. 94.

${ }^{30}$ MILL, John Stuart. Sobre a liberdade. Tradução Alberto da Rocha Barros. 2. ed. Rio de Janeiro: Vozes, 1991. p. 94.
} 
A terceira razão para se manter a liberdade de expressão e se opor à censura, é que, mesmo totalmente falsa, a informação ou opinião censurada ajuda a prevenir que opiniões se tornarem dogmas. Mill acredita que a verdade não será assimilada como preconceito "se aceitar ser, e efetivamente for, vigorosa e ardentemente contestada". ${ }^{31} \mathrm{Na}$ quarta razão, Mill reitera que uma opinião, como um dogma, se não for contestada, perderá seu próprio sentido. ${ }^{32}$

Em relação à busca da verdade, Brink entende que a promoção da liberdade de expressão causa uma relação de proporção entre crenças verdadeiras e falsas na sociedade, baseando na visão do juiz da Suprema Corte Americana no caso Abrams vs United States, onde o magistrado entendeu que "o melhor teste a ser aplicado relativo à verdade é o da livre troca no mercado de ideias". ${ }^{33}$

O autor ainda reflete sobre o critério conservador de censura, onde se permite censurar informações e opiniões claramente falsas, que vão em desencontro com a verdade, como por exemplo, vedar aqueles que entendem que a Terra é plana. ${ }^{34}$ Tal exemplo vai ao encontro da tese de Mill, mais especificamente na terceira razão, onde é sustentado que a liberdade de expressão é necessária para prevenir que crenças verdadeiras se tornem dogmas.

Nesse mesmo sentido, no ano de 1907, quando da discussão acerca do crime de desacato à autoridade na Suprema Corte Americana, o Juiz Holmes ressaltou que o escopo da primeira emenda era proibir a restrição prévia "e acrescentou que até mesmo afirmações verdadeiras poderiam ser punidas caso se mostrassem danosas para o processo judicial". ${ }^{35}$

Deve-se observar, entretanto, que Mill e outros autores liberais reconhecem que a liberdade de expressão pode ser restringida. Para Mill, o princípio do dano restringe a liberdade de expressão, ou seja, se uma informação ou opinião causa danos significativos, esse discurso deve ser restringindo pelo Estado, da maneira menos restritiva possível. Todavia, como dito, trata-se de exceção, e segundo Brink, o discurso de ódio não se enquadra na classe de restrição legitima da liberdade fundamental, pois para o autor, Mill é bastante claro ao dizer que "meras

\footnotetext{
${ }^{31}$ MILL, John Stuart. Sobre a liberdade. Tradução Alberto da Rocha Barros. 2. ed. Rio de Janeiro: Vozes, 1991. p. 94.

32 MILL, John Stuart. Sobre a liberdade. Tradução Alberto da Rocha Barros. 2. ed. Rio de Janeiro: Vozes, 1991. p. 94/95.

33 BRINK, Davi O. Princípios de Millian, liberdade de expressão e discurso de ódio. In: SAMPAIO, José Adércio Leite (Coord.). Liberdade de expressão no século XXI. Belo Horizonte: Del Rey, 2016. p. 33.

${ }^{34}$ BRINK, Davi O. Princípios de Millian, liberdade de expressão e discurso de ódio. In: SAMPAIO, José Adércio Leite (Coord.). Liberdade de expressão no século XXI. Belo Horizonte: Del Rey, 2016. p. 33.

35 DWORKIN, Ronald. 0 direito da liberdade: a leitura moral da Constituição norte-americana. Tradução Marcelo Brandão Cipolla. São Paulo: Martins Fontes, 2006. p. 314.
} 
ISSN 1981-3694

(DOI): $10.5902 / 1981369430692$

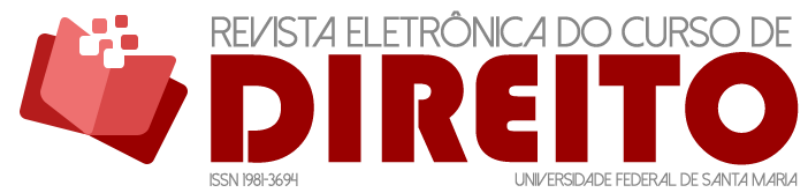

UMA ABORDAGEM COMPARADA ACERCA DO DISCURSO DE ÓDIO ENTRE BRASIL E ESTADOS UNIDOS

MigueL TEDESCO WEDY LENON OLIVEIRA HORBACH

ofensas não constituem dano a outrem", quando da fundamentação do princípio do dano. ${ }^{36}$

Como modelo, bem como sob forma de fundamentar a prevalência do direito à liberdade de expressão frente a outros direitos, assim como em relação à proteção e tutela de discursos carregados de ódio, ressalva-se a proteção dada pela jurisprudência norte americana, que desde o fim da Primeira Guerra Mundial tem valorizado cada vez mais o direito fundamental em seus precedentes constitucionais. ${ }^{37}$ Sunstein reitera que o direito à liberdade de expressão ganhou força pouco após a Primeira Guerra Mundial, pois antes de 1919 poucas eram as manifestações favoráveis da corte americana em razão do free speech. ${ }^{38}$

A proteção à liberdade de expressão nos Estados Unidos é considerada como um valor humanista, produto da construção histórica do país, refletindo sua cultura. ${ }^{39} \mathrm{~A}$ preocupação para com os valores humanísticos se justifica em proteger "más ideias” e “discursos prejudiciais”, ao invés de censurá-los ou restringi-los. ${ }^{40}$ Esse direito fundamental foi incorporado a Constituição americana ainda no ano de 1791, conhecida como the first amendment, entre as dez emendas que compuseram a chamada Bill of rights. ${ }^{41}$

Robert Sedler faz um contraste entre EUA e países europeus, mostrando que estes últimos não toleram expressões que carregam ódio, uma vez que, durante as guerras mundiais, principalmente na Segunda Guerra Mundial, suportaram agressões terríveis ocasionadas pelos nazistas e fascistas, motivo pelo qual abominam quaisquer discursos ou exibição de símbolos nazifascistas ou defesa ao genocídio. ${ }^{42}$

Dessa forma, diferente dos países europeus, desde o fim das guerras mundiais, a Suprema Corte Americana dá interpretação expansiva à primeira emenda constitucional, como

${ }^{36}$ BRINK, Davi O. Princípios de Millian, liberdade de expressão e discurso de ódio. In: SAMPAIO, José Adércio Leite (Coord.). Liberdade de expressão no século XXI. Belo Horizonte: Del Rey, 2016. p. 54.

37 SARMENTO, Daniel. LIVRES E IGUAIS: Estudos de Direito Constitucional. Rio de Janeiro: Lumen Juris, 2006. p. 210/211.

${ }^{38}$ SUNSTEIN, Cass R. Democracy and the problem of free speech. Nova lorque: The Free Press, 1995. p. 4.

${ }^{39}$ Sem desconsiderar, é claro, que durante a Guerra Civil americana, várias garantias foram desprezadas pelo Poder Executivo, como o próprio habeas corpus.

40 SEDLER, Robert A. Um ensaio sobre a liberdade de expressão: Os Estados Unidos versus o resto do mundo. In: SAMPAIO, José Adércio Leite (Coord.). Liberdade de expressão no século XXI. Belo Horizonte: Del Rey, 2016. p. 89.

${ }^{41}$ Congress shall make no law respecting a establishment of religion, or prohibiting the free exercise thereof; or abridging the freedom of speech, or of the press, or the right of the people peaceably to assemble, and to petition the government for redress of grievances. Disponível em: http: / / constitutionus.com/. Acessado em: 4 ago. 2017.

42 SEDLER, Robert A. Um ensaio sobre a liberdade de expressão: Os Estados Unidos versus o resto do mundo. In: SAMPAIO, José Adércio Leite (Coord.). Liberdade de expressão no século XXI. Belo Horizonte: Del Rey, 2016. p. 89. 
ISSN 1981-3694

(DOI): 10.5902/1981369430692

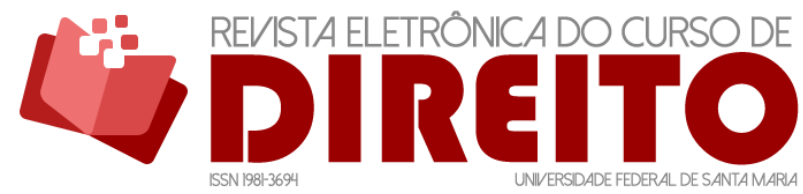

UMA ABORDAGEM COMPARADA ACERCA DO DISCURSO DE ÓDIO ENTRE BRASIL E ESTADOS UNIDOS

MIGUEL TEDESCO WEDY LENON OLIVEIRA HORBACH

forma de implementação dos valores e objetivos da sociedade democrática americana. ${ }^{43}$ Entende-se que o Estado norte-americano deve adotar uma postura neutra frente à manifestação de pensamento, ainda que as considere desprezíveis ou perigosas. ${ }^{44}$

Exemplo de que discursos hediondos não são vedados nos EUA foi o caso emblemático do município de Skokie, no subúrbio de Chicago. À época, o município contava com cerca de 70.000 habitantes, entre eles 40.000 judeus, e aproximadamente 5.000 sobreviventes do Holocausto. Aconteceu que o Partido Nacional Socialista da América promoveu uma passeata em que os militantes estavam vestindo uniformes militares nazistas, levantando bandeiras com a suástica. ${ }^{45}$

O Município tentou impedir a manifestação via judicial, conforme o precedente Skokie Vs. Nationalist Socialist Party of America, todavia a ação foi julgada improcedente. O Munícipio, então, editou leis tentando criar obstáculos a eventos, entretanto a legislação foi declarada inconstitucional. De qualquer forma, o protesto deixou de ser realizado na cidade de Skokie devido à resistência municipal, e foi realizado em Chicago, com escolta policial. Nesse sentido, sintetiza-se que tanto as ideias defendidas por Hitler, quanto às ideias defendidas por militantes de Direitos Humanos, devem receber a mesma proteção do poder público em razão de sua manifestação. ${ }^{46}$

Sunstein explica que, por três décadas seguidas, discutiu-se fortemente a abrangência ampla do direito à liberdade de expressão nos EUA (1930 - 1960), através de duas linhas de pensamento sustentadas por juízes da Suprema Corte Americana. A primeira (representada pelos juízes da Suprema Corte Hugo Black e Willian Douglas) acreditava no absolutismo da primeira emenda, onde: 0 governo era opressor da liberdade de expressão; A primeira emenda deveria ser observada com neutralidade em relação ao conteúdo do discurso que se analisa; 0 direito à liberdade de expressão não se limita à seara política ou ao discurso politizado; Qualquer restrição a primeira emenda serviria como tendência a se expandir outras decisões no mesmo sentido; A proporção entre direitos conflitantes, não deveria acontecer em relação a liberdade de expressão. ${ }^{47}$

\footnotetext{
43 SEDLER, Robert A. Um ensaio sobre a liberdade de expressão: Os Estados Unidos versus o resto do mundo. In: SAMPAIO, José Adércio Leite (Coord.). Liberdade de expressão no século XXI. Belo Horizonte: Del Rey, 2016. p. 89.

${ }^{44}$ SARMENTO, Daniel. LIVRES E IGUAIS: Estudos de Direito Constitucional. Rio de Janeiro: Lumen Juris, 2006. p. 215.

45 SARMENTO, Daniel. LIVRES E IGUAIS: Estudos de Direito Constitucional. Rio de Janeiro: Lumen Juris, 2006. p. 214.

${ }^{46}$ SARMENTO, Daniel. LIVRES E IGUAIS: Estudos de Direito Constitucional. Rio de Janeiro: Lumen Juris, 2006. p. 210/211.

${ }^{47}$ SUNSTEIN, Cass R. Democracy and the problem of free speech. Nova lorque: The Free Press, 1995. p. 4-7.
} 
ISSN 1981-3694

(DOI): 10.5902/1981369430692

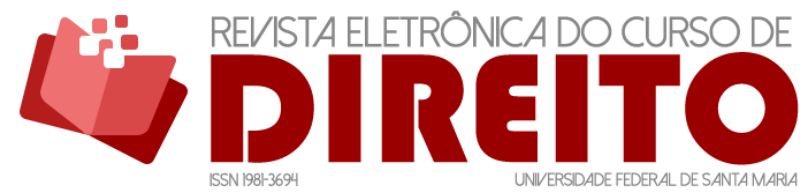

UMA ABORDAGEM COMPARADA ACERCA DO DISCURSO DE ÓDIO ENTRE BRASIL E ESTADOS UNIDOS

MIGUEL TEDESCO WEDY LENON OLIVEIRA HORBACH

A segunda linha de pensamento (representada pelo juiz da Suprema Corte Felix Frankfurter) acreditava na tese do reasonable regulation da primeira emenda, ponderando-se princípios e direitos. Para os defensores desta linha de pensamento, a primeira emenda não protegida discursos de apologia ao crime, discursos publicitários, hate speech, obscenidade, etc. ${ }^{48}$ Segundo Sunstein ainda, aparentemente, a linha absolutista não ganhou tantos adeptos na Suprema Corte, todavia, ressalta que há uma série de decisões favoráveis, protegendo apologia ao crime, variados tipos de ofensas, discursos publicitários, sob a proteção da primeira emenda. ${ }^{49}$

Para o autor, o desenvolvimento de teses acerca do direito fundamental à liberdade de expressão contribuiu para o sistema atual ser relativamente simples, pois está estribado na resposta de dois questionamentos, que devem ser respondidos para se obter resultados sobre a razoabilidade de restrição de direitos. A primeira pergunta compreende o valor do discurso em questão, fazendo distinção entre discursos de pouco e elevado valor. Já o segundo questionamento indaga se o governo regulou o discurso de maneira neutra, no sentido de que não cabe ao governo regular discursos, salvo se respeitado o requisito da neutralidade em relação ao conteúdo. ${ }^{50}$

Outrossim, referindo-se à segunda linha de pensando anteriormente referida por Sunstein, em relação a obscenidade e pornografia, vale ressalvar as lições de Dworkin. Por mais que a Suprema Corte insista em dizer que obscenidade não é protegida pela primeira emenda, uma vez que "não teria nenhum valor social que a redimisse", ${ }^{51}$ destaca-se que em uma sociedade onde a pornografia pesada é liberada, há mais condições de descobrir verdades sobre qualquer coisa. ${ }^{52}$ A Suprema Corte, segundo Dworkin, tem dificuldade de identificar e distinguir o que é obscenidade, daquilo que são representações explícitas de sexo que contem valor social que as redima.

No ano de 1973, o juiz da Suprema Corte, Brennan, declarou que "caso não haja distribuição para menores nem a exposição ostensiva a adultos que não deem seu

\footnotetext{
${ }^{48}$ SUNSTEIN, Cass R. Democracy and the problem of free speech. Nova lorque: The Free Press, 1995. p. 4-7.

${ }^{49}$ SUNSTEIN, Cass R. Democracy and the problem of free speech. Nova lorque: The Free Press, 1995. p. 8.

${ }^{50}$ SUNSTEIN, Cass R. Democracy and the problem of free speech. Nova lorque: The Free Press, 1995. p. 8-9.

51 DWORKIN, Ronald. 0 direito da liberdade: a leitura moral da Constituição norte-americana. Tradução Marcelo Brandão Cipolla. São Paulo: Martins Fontes, 2006. p. 332.

52 DWORKIN, Ronald. 0 direito da liberdade: a leitura moral da Constituição norte-americana. Tradução Marcelo Brandão Cipolla. São Paulo: Martins Fontes, 2006. p. 332.
} 
ISSN 1981-3694

(DOI): 10.5902/1981369430692

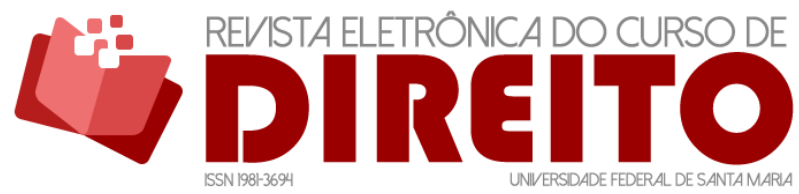

UMA ABORDAGEM COMPARADA ACERCA DO DISCURSO DE ÓDIO ENTRE BRASIL E ESTADOS UNIDOS

MIGUEL TEDESCO WEDY LENON OLIVEIRA HORBACH

consentimento" a obscenidade seria permitida, pois não cabe ao Estado censurar pornografia. Grupos ativistas formados por feministas entendem que a representação explicita de sexo faz mal às mulheres, uma vez que apresentam estas como objetos de exploração e abuso sexual. Entretanto, esse mal é próximo da simples ofensa, não sendo razão válida para constituir censura. ${ }^{53}$

Durante toda a história antiga, a pornografia esteve presenta na vida das pessoas, como algo normal, exemplo disso são alguns Deuses que foram representados através de imagens pornográficas, representando a celebração do sexo, sem qualquer desconforto. ${ }^{54}$

Para além da obscenidade, Dworkin fundamenta que a liberdade de expressão é importante não só pelas consequências que ela traz, "mas porque o Estado deve tratar todos os cidadãos adultos (com exceção dos incapazes) como agentes morais responsáveis”, sendo traço essencial de uma sociedade política justa. Antes ainda, o autor entende que a liberdade de expressão não é importante para que as pessoas possam dizer aquilo que pensam, mas sim "porque a permissão de que elas digam produzirá efeitos benéficos para o conjunto da sociedade". 55

Em um contexto americano, a liberdade de expressão dá subsídio à proteção do poder soberano emanado do povo, ao mesmo tempo que "o governo tende a se tornar menos corrupto quando não tem o poder de punir aqueles que o criticam". O Estado acaba por ofender os seus cidadãos quando decreta que esses não têm "qualidade moral suficiente para ouvir opiniões que possam persuadi-los de convicções perigosas ou desagradáveis". Dessa forma, concorda Dworkin, conservamos nossa dignidade individual quando ninguém, muito menos o Estado, nos impede de ouvir uma opinião por medo de que não estejamos seguros de ouvi-la e suportá-la.

Sunstein ainda apresenta outra versão sobre o sistema de proteção da liberdade de expressão norte-americano, não se baseando no valor do discurso, mas sim no método pelo qual o governo o regula, sintetizando três métodos de restrição de discursos, todas a partir de seus conteúdos. A primeira são as restrições neutras, sendo aquelas que, na verdade, não se fundam

\footnotetext{
${ }^{53}$ DWORKIN, Ronald. 0 direito da liberdade: a leitura moral da Constituição norte-americana. Tradução Marcelo Brandão Cipolla. São Paulo: Martins Fontes, 2006. p. 331.

54 SAUNDERS, Kevin W. Degradation: What the history of obscenity tells us about hate speech. Nova lorque: New York University, 2011. p. 7-26.

55 DWORKIN, Ronald. 0 direito da liberdade: a leitura moral da Constituição norte-americana. Tradução Marcelo Brandão Cipolla. São Paulo: Martins Fontes, 2006. p. 318/319.
} 
ISSN 1981-3694

(DOI): $10.5902 / 1981369430692$

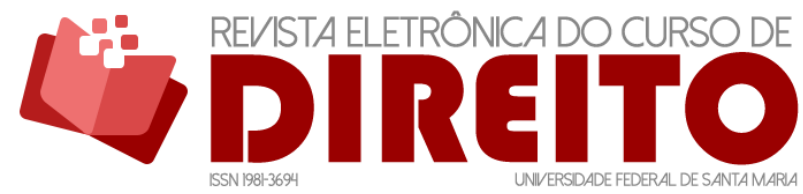

UMA ABORDAGEM COMPARADA ACERCA DO DISCURSO DE ÓDIO ENTRE BRASIL E ESTADOS UNIDOS

MIGUEL TEDESCO WEDY LENON OLIVEIRA HORBACH

no conteúdo, pois este seria um fato irrelevante para a restrição, ou seja, as restrições neutras não se importam com os conteúdos do discurso. ${ }^{56}$

A segunda possibilidade de restrição se baseia no ponto de vista do emissor do discurso, que privilegia um determinado lado ou uma opinião, silenciando outros pontos de vista a respeito de certo assunto, entretanto permitindo que as outras opiniões sejam livremente expressas. A terceira, se baseia no conteúdo do discurso, sendo neutra em relação ao ponto de vista, ou seja, não elege lados como a segunda, vedando qualquer tipo de opinião sobre determinado conteúdo. Em resumo, o autor conclui que as restrições em razão de pontos de vista são com certeza inconstitucionais, enquanto as restrições baseadas no conteúdo gozam de presunção de inconstitucionalidade, ao tempo que as restrições neutras em relação ao conteúdo se submetem a testes de nivelamento. ${ }^{57}$

James Weinstein confirma que a doutrina americana em relação à liberdade de expressão é hostil às restrições baseadas em conteúdo, e sintetiza o entendimento citando o caso Police Dep't of Chicago vs Mosley, no ano de 1972, onde a Suprema Corte decidiu que um restrição baseada em conteúdo é presumida inconstitucional de acordo com a primeira emenda, salvo quando houver argumentos convincentes (compelling rights), aptos a justificar a restrição. ${ }^{58}$

É possível afirmar claramente que há uma valorização da liberdade em relação à igualdade na tradição norte-americana, justificando-se pela profunda desconfiança em relação ao Estado, em face do mercado, principalmente no que tange à discussão de ideias. Há uma visão no direito constitucional americano de que o Estado é inimigo dos direitos, e não uma entidade promotora de direitos, o que ocasiona uma jurisprudência libertária. ${ }^{59}$

Em contrário, Sarmento traz críticas ao modelo americano, onde:

Deve-se referir ainda à subsistência, no pensamento constitucional norteamericano, da anacrônica visão de que os direitos e princípios constitucionais só vinculam ao Estado, não criando nenhum tipo de obrigação para os particulares. Essa concepção, superada na maior parte das constituições contemporâneas, em cada vez mais se tem reconhecido uma eficácia também horizontal dos direitos fundamentais, expressa-se no direito americano através da doutrina da State

\footnotetext{
${ }^{56}$ SUNSTEIN, Cass R. Democracy and the problem of free speech. Nova lorque: The Free Press, 1995. p. 11-13.

57 SUNSTEIN, Cass R. Democracy and the problem of free speech. Nova lorque: The Free Press, 1995. p. 11-13.

${ }^{58}$ WEINSTEIN, James. An overview of american free speech doctrine and its application to extreme speech. In: HARE, Ivan; WEINSTEIN, James. Extreme speech and democracy. Oxford: Oxford University, 2009. p. 81.

59 SARMENTO, Daniel. LIVRES E IGUAIS: Estudos de Direito Constitucional. Rio de Janeiro: Lumen Juris, 2006. p. 217/218.
} 
ISSN 1981-3694

(DOI): 10.5902/1981369430692

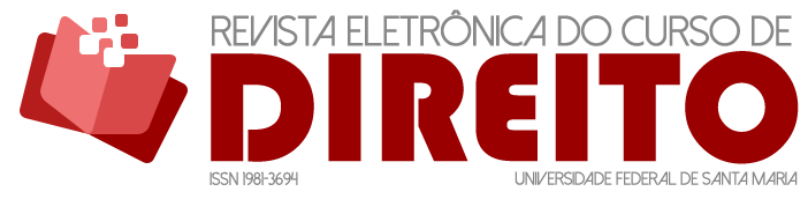

UMA ABORDAGEM COMPARADA ACERCA DO DISCURSO DE ÓDIO ENTRE BRASIL E ESTADOS UNIDOS

MIGUEL TEDESCO WEDY LENON OLIVEIRA HORBACH

Action. Sob o prisma dessa doutrina, o racismo, o preconceito, e a intolerância do Estado e das autoridades públicas violam a Constituição, mas os mesmos comportamentos, quando praticados por agentes privados, tornando-se "indiferentes" constitucionais. ${ }^{60}$

Para o autor essa concepção formalista de liberdade de expressão abstrai a real opressão "exercida no mundo da vida sobre os sujeitos de carne e osso". Essa visão negligencia os constrangimentos do mundo fático, acabando por empobrecer a liberdade, uma vez que o não há coação estatal sobre os indivíduos, ou seja, não há nenhuma força silenciadora sobre os discursos opressivos e intolerantes. ${ }^{61}$ É fato que existe diversidade no pensamento norte americano, com visões e cosmovisões mais sensíveis em relação a igualdade para a proteção de minorias, muitas vezes alvos de discursos intolerantes. ${ }^{62}$

Curioso ainda é que a questão do Hate Speech nos EUA ocasionou uma verdadeira ruptura entre os defensores de direitos humanos. Antes da discussão acerca da tutela do discurso de ódio, o direito à liberdade de expressão e a defesa dos direitos das minorias estavam do mesmo lado. Tinham-se sempre de um lado a direita conservadora, querendo banir o espaço livre de ideias, e do outro a esquerda, na luta pelos direitos de grupos minoritários. Entretanto, de repente, a liberdade de expressão passou a ser vista "não mais como um instrumento de emancipação, mas como um escudo em favor da opressão de grupos estigmatizados". ${ }^{63}$

Uma distinção importante, segundo Meyer-Pflug, se dá entre discursos que carregam ódio explicito, de fácil identificação, daqueles implícitos. No primeiro trata-se de manifestação explicitamente tendente a diminuir, retirar direitos, discriminar, ou meramente ofender grupos em razão de condições. Já o segundo aparece de forma implícita, de maneira subliminar, subjacente ao discurso, como por exemplo em charges que ofendam religiões, em comerciais de televisão, entre outras formas. ${ }^{64} 0$ discurso de ódio implícito pode estar, por vezes, institucionalizado, como na França, que no ano de 2014 proibiu o uso de vestes típicas referente à religião muçulmana em espaços públicos, sendo a vedação endossada pelo Tribunal Europeu de

\footnotetext{
60 SARMENTO, Daniel. LIVRES E IGUAIS: Estudos de Direito Constitucional. Rio de Janeiro: Lumen Juris, 2006. p. 218.

${ }^{61}$ SARMENTO, Daniel. LIVRES E IGUAIS: Estudos de Direito Constitucional. Rio de Janeiro: Lumen Juris, 2006. p. 217.

62 SARMENTO, Daniel. LIVRES E IGUAIS: Estudos de Direito Constitucional. Rio de Janeiro: Lumen Juris, 2006. p. 219.

${ }^{63}$ SARMENTO, Daniel. LIVRES E IGUAIS: Estudos de Direito Constitucional. Rio de Janeiro: Lumen Juris, 2006. p. 219.

${ }^{64}$ MEYER-PFLUG, Samantha Ribeiro. Liberdade de Expressão e discurso do ódio. São Paulo: Editora Revista dos Tribunais, 2009. p. 99.
} 
ISSN 1981-3694

(DOI): $10.5902 / 1981369430692$

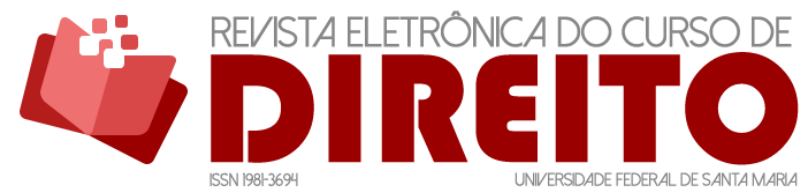

UMA ABORDAGEM COMPARADA ACERCA DO DISCURSO DE ÓDIO ENTRE BRASIL E ESTADOS UNIDOS

Miguel TEDESCO WedY LENON OLIVEIRA HORBACH

Direitos Humanos. ${ }^{65}$ Destaca-se ainda que tanto o Brasil quanto os EUA são signatários do Pacto Internacional sobre direitos Civis e Políticos, que prevê em seu artigo $19^{\circ}$ total proteção ao direito de opinião e de expressã $0^{66}$, enquanto o artigo $20^{\circ}$ veda qualquer propaganda a guerra ou defesa de ódio nacional, racial, ou religioso que estimule a discriminação, hostilidade ou violência. ${ }^{67}$ O Senado Americano promulgou resolução com reserva ao artigo $20^{\circ}$ da convenção, não autorizando nenhuma lei ou qualquer outra ação dos Estados que restrinja o direito de liberdade de expressão, já anteriormente protegidos pela Constituição dos EUA. ${ }^{68}$

\title{
3 A LIBERDADE DE EXPRESSÃO NO BRASIL: A NECESSIDADE DE DIMINUIÇÃO DAS DESIGUALDADES SOCIAIS
}

No Brasil, o direito à liberdade de expressão está positivado em várias partes da Constituição Federal de 1988, como nos incisos IV $,^{69} \mathrm{IX},{ }^{70}$ e $\mathrm{XIV}^{71}$ do artigo $5^{\circ}$, o que evidencia sua

\begin{abstract}
${ }^{65}$ CAVALCANTE SEGUNDO, Antonio de Holanda. Uma questão de opinião? Liberdade de expressão e seu âmbito protetivo: da livre manifestação do pensamento ao hate speech. 1. ed. Rio de Janeiro: Lumen Juris, 2016. p. 61.

66 Art. 19: 1. Ninguém poderá ser molestado por suas opiniões. 2. Toda pessoa terá direito à liberdade de expressão; esse direito incluirá a liberdade de procurar, receber e difundir informações e idéias de qualquer natureza, independentemente de considerações de fronteiras, verbalmente ou por escrito, em forma impressa ou artística, ou por qualquer outro meio de sua escolha. 3. 0 exercício do direito previsto no parágrafo 2 do presente artigo implicará deveres e responsabilidades especiais. Conseqüentemente, poderá estar sujeito a certas restrições, que devem, entretanto, ser expressamente previstas em lei e que se façam necessárias para: a) assegurar o respeito dos direitos e da reputação das demais pessoas; b) proteger a segurança nacional, a ordem, a saúde ou a moral pública. Disponível em: http://www.planalto.gov.br/ccivil_03/decreto/1990-1994/d0592.htm, Acessado em: 04 de ago. 2017.

${ }_{67}$ Art. 20:1. Será proibida por lei qualquer propaganda em favor da guerra.2. Será proibida por lei qualquer apologia do ódio nacional, racial ou religioso que constitua incitamento à discriminação, à hostilidade ou a violência. Disponível em: http://www.planalto.gov.br/ccivil_03/decreto/19901994/d0592.htm, Acessado em: 04 de ago. 2017.
\end{abstract}

${ }_{68}$ SEDLER, Robert A. Um ensaio sobre a liberdade de expressão: Os Estados Unidos versus o resto do mundo. In: SAMPAIO, José Adércio Leite (Coord.). Liberdade de expressão no século XXI. Belo Horizonte: Del Rey, 2016. p. 91.

69 IV - é livre a manifestação do pensamento, sendo vedado o anonimato. BRASIL. Constituição (1988). Constituição da República Federativa do Brasil. Brasília, DF: Senado Federal. Disponível em: http://www.planalto.gov.br/ccivil_03/constituicao/constituicaocompilado.htm. Acessado em: 04 de ago. de 2017.

70 IX - É livre a expressão da atividade intelectual, artística, científica e de comunicação, independentemente de censura ou licença. BRASIL. Constituição (1988). Constituição da República Federativa do Brasil. Brasília, DF: Senado Federal. Disponível em: http://www.planalto.gov.br/ccivil_03/constituicao/constituicaocompilado.htm. Acessado em: 04 de ago. 2017.

71 XIV - é assegurado a todos o acesso à informação e resguardado o sigilo da fonte, quando necessário ao exercício professional. BRASIL. Constituição (1988). Constituição da República Federativa do Brasil. Brasília, DF: Senado Federal. 
ISSN 1981-3694

(DOI): $10.5902 / 1981369430692$

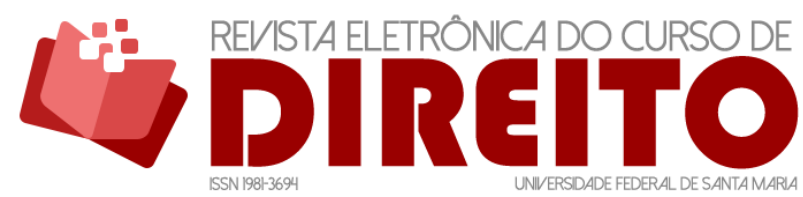

UMA ABORDAGEM COMPARADA ACERCA DO DISCURSO DE ÓDIO ENTRE BRASIL E ESTADOS UNIDOS

Miguel TEDESCO WeDY LENON OLIVEIRA HORBACH

natureza constitucional como direito fundamental desdobrado a partir de uma perspectiva de dignidade da pessoa humana, assim como confirmado direito humano, registrado em várias convenções e documentos internacionais.

Sarlet entende que, na Constituição de 1988, a liberdade de expressão, além de ser objeto de detalhada positivação, traduz sua compatibilidade com o Estado Democrático de Direito, ${ }^{72}$ na medida em que é pertinente destacar que a relação entre liberdade de expressão e democracia é de caráter complementar, dialético e dinâmico, onde, quanto mais democracia, mais liberdade de expressão e vice-versa, entretanto é correto também afirmar que "a liberdade de expressão pode acarretar riscos para a democracia, e esta, para a liberdade de expressão. ${ }^{73}$

É compreensível que, no sistema brasileiro, a partir de uma perspectiva histórica, a liberdade de expressão tenha posição superior a outros direitos. Nas palavras de Sarmento, "trata-se de exorcizar os fantasmas do regime militar, que praticaram aberta censura política e artística, e de assegurar as bases para a construção de uma sociedade mais livre e democrática", ${ }^{74}$ porém ao mesmo tempo o autor entende que há valores constitucionais fundamentais que podem colidir em face da liberdade de expressão, como o devido processo legal, a saúde, a igualdade, etc. ${ }^{75}$

Em relação à tutela de discurso de ódio, a Constituição de 88 tem firmado compromisso com a construção da igualdade e erradicação do preconceito. Tal obrigação é destacada no artigo $3^{\circ}$ do texto magno, onde apresentados os objetivos da República Federativa. ${ }^{76}$ Diferente do Estado americano, o constituinte não atribuiu ao Estado brasileiro "o papel de espectador neutro e imparcial dos conflitos travados na esfera social". ${ }^{77}$

http://www.planalto.gov.br/ccivil_03/constituicao/constituicaocompilado.htm. Acessado em: 04 de ago. 2017.

72 SARLET, Ingo Wolfgang; MARINONI, Luiz Guilherme. MITIDIEIRO, Daniel. Curso de Direito Constitucional. 4. ed. ampl. São Paulo: Saraiva, 2015. p. 485.

73 SARLET, Ingo Wolfgang; MARINONI, Luiz Guilherme. MITIDIEIRO, Daniel. Curso de Direito Constitucional. 4. ed. ampl. São Paulo: Saraiva, 2015. p. 488.

74 SARMENTO, Daniel. LIVRES E IGUAIS: Estudos de Direito Constitucional. Rio de Janeiro: Lumen Juris, 2006. P. 250.

75 SARMENTO, Daniel. LIVRES E IGUAIS: Estudos de Direito Constitucional. Rio de Janeiro: Lumen Juris, 2006. p. $250 / 251$.

${ }^{76}$ Art. $3^{\circ}$ Constituem objetivos fundamentais da República Federativa do Brasil:I - construir uma sociedade livre, justa e solidária; II - garantir o desenvolvimento nacional; III - erradicar a pobreza e a marginalização e reduzir as desigualdades sociais e regionais; IV - promover o bem de todos, sem preconceitos de origem, raça, sexo, cor, idade e quaisquer outras formas de discriminação. BRASIL. Constituição (1988). Constituição da República Federativa do Brasil. Brasília, DF: Senado Federal. Disponível em: http://www.planalto.gov.br/ccivil_03/constituicao/constituicaocompilado.htm. Acessado em: 04 de ago. 2017.

77 SARMENTO, Daniel. LIVRES E IGUAIS: Estudos de Direito Constitucional. Rio de Janeiro: Lumen Juris, 2006. p. 251. 
Uma premissa empírica, para que não se aceite discursos intolerantes, é a grande desigualdade e injustiça existente na sociedade brasileira, que reproduz intolerância e preconceito diariamente. O Constituinte impôs aos três poderes tarefas de inclusão social, bem como transformações de práticas opressivas em face de grupos estigmatizados, buscando, como dito, uma sociedade igualitária ${ }^{78}$.

Assim, o direito à igualdade não estaria centrado exclusivamente na relação entre Estado e indivíduo, pelo contrário, frente à ubiquidade da injustiça e opressão, o sistema adotaria o princípio da eficácia horizontal dos direitos fundamentais, onde os direitos vinculariam e obrigariam também os particulares, mesmo que de forma diferenciada. ${ }^{79}$

Dessa forma, afirma-se que a Constituição brasileira não vedou apenas o Estado de atos discriminatórios, de preconceito e intolerância, mas também em relação a cada cidadão e entidades privadas:

A constituição de 88 não é libertária e não associa a liberdade humana à simples abstenção estatal. Pelo contrário, ela se preocupa com a efetiva possibilidade de fruição da liberdade pelos indivíduos, o que supõe o enfrentamento dos obstáculos sociais que atravancam o seu exercício, presentes em uma sociedade desigual e opressiva. Essa compreensão mais realista da autonomia individual projeta-se no campo da liberdade de expressão e ampara a pretensão estatal de coibir as manifestações que silenciam as vezes de suas vítimas, com as envolvidas no hate speech. ${ }^{80}$

Episódio emblemático no Brasil que discutiu a tutela do discurso de ódio foi o Caso Ellwanger (HC n. 82.424-2/RS), onde se abordou no Supremo Tribunal Federal questão pertinente à liberdade de expressão frente ao discurso discriminatório. Na oportunidade, a Corte Suprema, por maioria, entendeu que o discurso de ódio não é compatível com os valores éticos e

${ }^{78}$ Esse compromisso igualitário se revela também no artigo $5^{\circ} / \mathrm{CF}$, onde o princípio da igualdade é afirmado no caput e reiterado no inciso I: Art. $5^{\circ}$ Todos são iguais perante a lei, sem distinção de qualquer natureza, garantindo-se aos brasileiros e aos estrangeiros residentes no País a inviolabilidade do direito à vida, à liberdade, à igualdade, à segurança e à propriedade, nos termos seguintes: I - homens e mulheres são iguais em direitos e obrigações, nos termos desta Constituição. BRASIL. Constituição (1988). Constituição da República Federativa do Brasil. Brasília, DF: Senado Federal. Disponível em: http://www.planalto.gov.br/ccivil_03/constituicao/constituicaocompilado.htm. Acessado em: 04 de ago. de 2017. SARMENTO, Daniel. LIVRES E IGUAIS: Estudos de Direito Constitucional. Rio de Janeiro: Lumen Juris, 2006. p. 251.

79 SARMENTO, Daniel. LIVRES E IGUAIS: Estudos de Direito Constitucional. Rio de Janeiro: Lumen Juris, 2006. p. 252.

80 SARMENTO, Daniel. LIVRES E IGUAIS: Estudos de Direito Constitucional. Rio de Janeiro: Lumen Juris, 2006. p. 252. 
ISSN 1981-3694

(DOI): $10.5902 / 1981369430692$

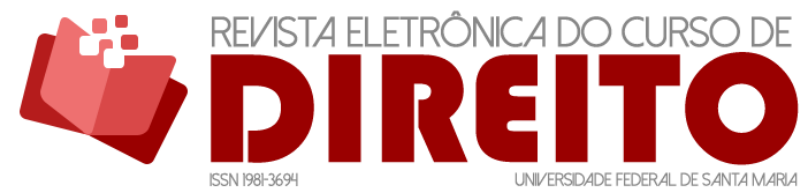

UMA ABORDAGEM COMPARADA ACERCA DO DISCURSO DE ÓDIO ENTRE BRASIL E ESTADOS UNIDOS

Miguel Tedesco WedY LENON OLIVEIRA HORBACH

jurídicos previstos na Constituição Federal, afastando qualquer possibilidade de tutela do discurso em questão. ${ }^{81}$

Em síntese, o caso tratava das obras publicadas pelo escritor e editor Siefried Ellwanger, onde o paciente defendia um revisionismo histórico em relação ao acontecimento do Holocausto do povo Judeu durante a Segunda Guerra Mundial. ${ }^{82}$

Ellwanger foi processado pelo crime de racismo, absolvido em primeira instância, sob argumento de que o réu estaria protegido pelo seu direito fundamental de liberdade de expressão. Foi, entretanto, condenado pelo Tribunal de Justiça do Estado do Rio Grande do Sul (TJRS), sob a justificativa de que o requerido estava fazendo apologia a ideias preconceituosas e discriminatórias contra os Judeus. O paciente impetrou Habeas Corpus junto ao Superior Tribunal de Justiça, o qual manteve a decisão, sob os mesmos fundamentos do TJRS. ${ }^{83}$

Em sequência, novo Habeas Corpus foi impetrado, dessa vez ao Supremo Tribunal Federal (STF), com argumento de que os Judeus não eram precisamente uma raça, de forma que não estaria configurado o crime de racismo. Em outras linhas, considera-se que o STF tenha enfrentado a tutela de discurso de ódio no Brasil desdobrado a partir de uma perspectiva de liberdade de expressão. ${ }^{84}$ Por maioria, oito ministros do STF decidiram que o paciente que não estava coberto pelo direito de liberdade de expressão quando publicou obras fazendo apologia antissemita, configurando-se crime de racismo. ${ }^{85}$

Para Sarmento, frente ao contexto brasileiro normativo e axiológico, não foi difícil ao Supremo Tribunal Federal decidir em desfavor do paciente, punindo-o pelas manifestações antissemitas, uma vez que o Brasil é signatário de tratados de convenções internacionais de direitos humanos, o que o obriga no combate a manifestações de racismo, preconceito e intolerância. É observado que esses instrumentos internacionais, quando incorporados, não só obrigam o Estado Brasileiro frente à comunidade global, mas também dentro do próprio país. ${ }^{86}$

\footnotetext{
81 BARROS, Caroline Maria Costa. A moral como instrumento limitador da liberdade de expressão: apontamentos sobre o exercício (i) legítimo do discurso de ódio. 1. ed. Rio de Janeiro: Lumen Juris, 2015. p. 246.

82 OMMATI, José Emílio Medauar. Liberdade de Expressão e discurso de ódio na Constituição de 1988. 3. ed. Rio de Janeiro: Lumen Juris, 2016. p. 22.

83 OMMATI, José Emílio Medauar. Liberdade de Expressão e discurso de ódio na Constituição de 1988. 3. ed. Rio de Janeiro: Lumen Juris, 2016. p. 22.

${ }^{84}$ OMMATI, José Emílio Medauar. Liberdade de Expressão e discurso de ódio na Constituição de 1988. 3. ed. Rio de Janeiro: Lumen Juris, 2016. p. 22/23.

85 OMMATI, José Emílio Medauar. Liberdade de Expressão e discurso de ódio na Constituição de 1988. 3. ed. Rio de Janeiro: Lumen Juris, 2016. p. 24.

${ }^{86}$ SARMENTO, Daniel. LIVRES E IGUAIS: Estudos de Direito Constitucional. Rio de Janeiro: Lumen Juris, 2006. p. 253.
} 
ISSN 1981-3694

(DOI): $10.5902 / 1981369430692$

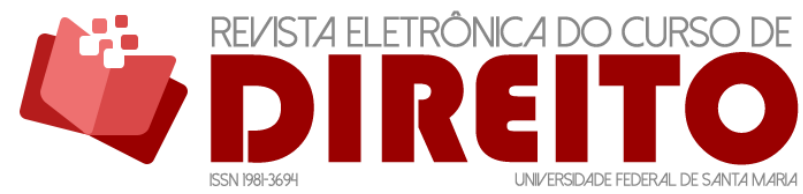

UMA ABORDAGEM COMPARADA ACERCA DO DISCURSO DE ÓDIO ENTRE BRASIL E ESTADOS UNIDOS

MigueL TEDESCO WeDY LENON OLIVEIRA HORBACH

Dessa forma, o STF confirmou ter uma visão comunitária sobre o tema, contrária ao liberalismo igualitário, onde o Estado apresenta "um papel significativo na redução das desigualdades sociais", devendo ser ativo e comprometido com a organização da vida pública, promovendo os valores comunitários. ${ }^{87}$

No caso Ellwanger, discutiu-se a possibilidade de ser democrático proteger, no sistema constitucional brasileiro os discursos carregados de ódio, uma vez que estes são direcionados a minorias que não possuem muitas formas de defesa. A conclusão se depreende ao reiterar que, no cenário atual brasileiro, "a não intervenção estatal no discurso político de expressão poderia gerar uma supressão das minorias, eliminando, ou minimizando, seu caráter comunicativo", configurando o efeito silenciador do discurso. Dessa forma, o discurso de ódio deve ser visto como uma conduta e não como discurso propriamente dito. ${ }^{88}$

Na mesma linha, Omatti vai mais além, sintetizando que a prática de discursos de ódio não limita a liberdade de expressão, uma vez que não se trataria de liberdade de expressão, mas sim o uso indevido de discursos que negam direitos fundamentais. ${ }^{89} \mathrm{O}$ autor conclui sua tese de doutorado confirmando que, ao contrário do que pensam os juristas, igualdade, liberdade de expressão e discurso de ódio não colidem e, portanto, não existem limitações de um direito em face de outro, onde:

Na linha da teoria do direito como integralidade, mostrarei que os conflitos entre direitos, sejam eles constitucionais ou não são apenas aparentes, na medida em que não existem direitos em si, mas a existência de um direito depende de toda uma argumentação jurídica e moral que pretende mostrar o enraizamento desse direito em nossa prática social. Assim, há colisões aparentes, que são tratadas, pela doutrina e jurisprudência majoritárias em nosso país como caso de colisão de princípios, pois os nossos juristas ainda confundem texto da norma com norma. ${ }^{90}$

Segundo o autor, por mais que o Brasil tenha passado por momentos difíceis durante a ditadura militar, em razão do ofuscamento do direito à liberdade de expressão, o que o levou a editar uma Constituição democrática com ênfase na liberdade de opinião, não se pode

87 BARROS, Caroline Maria Costa. A moral como instrumento limitador da liberdade de expressão: apontamentos sobre o exercício (i) legítimo do discurso de ódio. Rio de Janeiro: Lumen Juris, 2015. p. 247.

88 BARROS, Caroline Maria Costa. A moral como instrumento limitador da liberdade de expressão: apontamentos sobre o exercício (i) legítimo do discurso de ódio. Rio de Janeiro: Lumen Juris, 2015. p. 247.

89 OMMATI, José Emílio Medauar. Liberdade de Expressão e discurso de ódio na Constituição de 1988. 3. ed. Rio de Janeiro: Lumen Juris, 2016. p. 20.

${ }^{90}$ OMMATI, José Emílio Medauar. Liberdade de Expressão e discurso de ódio na Constituição de 1988. 3. ed. Rio de Janeiro: Lumen Juris, 2016. p. 32. 
ISSN 1981-3694

(DOI): $10.5902 / 1981369430692$

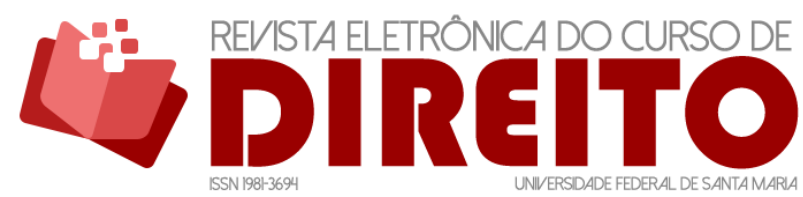

UMA ABORDAGEM COMPARADA ACERCA DO DISCURSO DE ÓDIO ENTRE BRASIL E ESTADOS UNIDOS

MIGUEL TEDESCO WEDY LENON OLIVEIRA HORBACH

considerar a vontade do legislador como estática, ou seja, retornando-se apenas ao momento histórico em que o texto normativo foi criado, mas sim, de uma maneira dinâmica atualizando o trabalho do legislador, indagando a interpretação que esse daria no momento presente. ${ }^{91}$

Em contrapartida, não se deve esquecer que na doutrina constitucional brasileira o direito à liberdade de expressão tem alto valor, só se admitindo como legítima regulação deste direito a que se fundamenta no próprio texto constitucional. ${ }^{92}$ A Constituição, no entanto, é precisa ao vedar a censura, através do artigo $5^{\circ}$, IX, já visto acima, bem como no $\$ 2^{\circ}$ do artigo 20, salientando que "é vedada toda e qualquer censura de natureza política, ideológica e artística". ${ }^{93}$

A própria Constituição em seu texto traz uma série de aparentes limitadores ao exercício da liberdade de expressão, que não a censura, como a vedação ao anonimato, o direito de resposta, a indenização pelo dano moral, material e a imagem, a inviolabilidade da intimidade, vida privada, honra, e imagem das pessoas. ${ }^{94}$ Tais restrições constitucionais refletem uma ampla legislação infraconstitucional que já regula as limitações à liberdade de expressão, dando concretude ao texto constitucional. Antevê-se, todavia, que tais limitações devem ser utilizadas de maneira ponderada e devem estar devidamente fundamentadas. ${ }^{95}$

Sarlet reforça que a liberdade de expressão, para assegurar sua posição destaque no âmbito das liberdades fundamentais, deve ser interpretada com a maior extensão possível, englobando "tanto a manifestação de opinião, quanto de ideias, pontos de vista, convicções, críticas, juízos de valor sobre qualquer matéria ou assunto e mesmo proposições a respeito de fatos. $^{96}$

${ }^{91}$ OMMATI, José Emílio Medauar. Liberdade de Expressão e discurso de ódio na Constituição de 1988. 3. ed. Rio de Janeiro: Lumen Juris, 2016. p. 32.

92 MEYER-PFLUG, Samantha Ribeiro. Liberdade de Expressão e discurso do ódio. São Paulo: Editora Revista dos Tribunais, 2009. p. 67.

${ }^{93}$ Art. 220. A manifestação do pensamento, a criação, a expressão e a informação, sob qualquer forma, processo ou veículo não sofrerão qualquer restrição, observado o disposto nesta Constituição. $\S 2^{\circ} \dot{E}$ vedada toda e qualquer censura de natureza política, ideológica e artística. BRASIL. Constituição (1988). Constituição da República Federativa do Brasil. Brasília, DF: Senado Federal. Disponível em: http://www.planalto.gov.br/ccivil_03/constituicao/constituicaocompilado.htm. Acessado em: 04 de ago. de 2017.

${ }^{94}$ CAVALCANTE SEGUNDO, Antonio de Holanda. Uma questão de opinião? Liberdade de expressão e seu âmbito protetivo: da livre manifestação do pensamento ao hate speech. Rio de Janeiro: Lumen Juris, 2016. p. 50.

${ }^{95}$ MEYER-PFLUG, Samantha Ribeiro. Liberdade de Expressão e discurso do ódio. São Paulo: Editora Revista dos Tribunais, 2009. p. 83.

96 SARLET, Ingo Wolfgang; MARINONI, Luiz Guilherme. MITIDIEIRO, Daniel. Curso de Direito Constitucional. 4. ed. ampl. São Paulo: Saraiva, 2015. p. 490. 
ISSN 1981-3694

(DOI): 10.5902/1981369430692

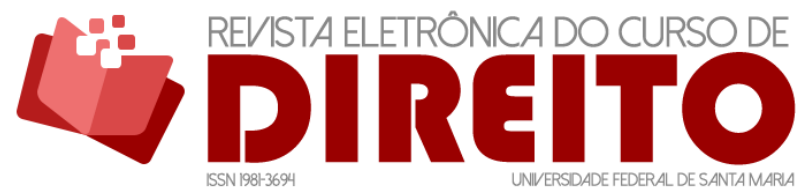

UMA ABORDAGEM COMPARADA ACERCA DO DISCURSO DE ÓDIO ENTRE BRASIL E ESTADOS UNIDOS

MIGUEL TEDESCO WEDY LENON OLIVEIRA HORBACH

Independente do respeito que se dá à efetividade proposta pelo constituinte ao direito de liberdade de expressão, deve-se ressalvar, ao cabo, o princípio da incensurabilidade e do pluralismo, como forma de reiterar a importância deste direito no Brasil. 0 primeiro implica que a sociedade possa expressar seus pensamentos e comunicar-se livremente de impedimentos ou interferências, assim como o segundo visa a que efetivamente os cidadãos se comuniquem, para que se concretize ampla divulgação de variedade de ideias e pontos de vistas de todas as partes da sociedade. ${ }^{97}$

\section{CONCLUSÃO}

Diante do que foi referido, percebe-se que a liberdade de expressão, tanto na cultura estado-unidense quanto na brasileira, ocupa um lugar especial na legislação constitucional, de modo que a discussão acerca da sua limitação ou regulação é atual e pertinente.

Quando analisada a tutela da liberdade de expressão frente aos discursos de ódio, tende-se a acreditar, instintivamente, que a liberdade de expressão deve ser pormenorizada, no sentido de diminuí-la. No cenário brasileiro, aparentemente, a liberdade de opinião não é tutelada quando usada para expressar discursos de ódio, partindo-se da premissa de que existe extrema desigualdade social, e, consequentemente, tais discursos fomentariam essa disparidade de poder social, o que influenciaria também a desigualdade política e econômica.

A grande parte da doutrina constitucional brasileira concorda no sentido da vedação da liberdade de expressão quando em razão de discursos de ódio, uma vez que o Brasil é signatários de diversas convenções internacionais de direitos humanos, bem assim em decorrência dos objetivos da República, que são construir uma sociedade livre, justa, e solidária, sem preconceitos, promovendo a igualdade e o bem-estar social.

Na primeira oportunidade de manifestação acerca do tema discurso de ódio, a Suprema Corte se manifestou, como previsto, contrária à tutela destas expressões, vendando qualquer ato discriminatório, frisando a necessidade de uma postura ativa por parte do Estado ao dar uma resposta aos conflitos que envolvem valores da comunidade brasileira.

A Constituição brasileira, como bem ressalvado durante o texto, traduz um Estado inverso àquele da Ditadura Militar, que negava direito e calava vozes, sendo compreensível a necessidade da CF/88 em proteger a liberdade de expressão. Porém, como fundamentado

${ }^{97}$ FARIAS, Edilson. Liberdade de Expressão e Comunicação: teoria e proteção constitucional. São Paulo: Editora Revista dos Tribunais, 2004. p. 76. 
ISSN 1981-3694

(DOI): 10.5902/1981369430692

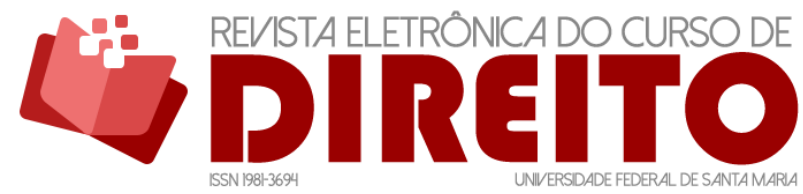

UMA ABORDAGEM COMPARADA ACERCA DO DISCURSO DE ÓDIO ENTRE BRASIL E ESTADOS UNIDOS

MIGUEL TEDESCO WEDY LENON OLIVEIRA HORBACH

acima, não se deveria incluir a possibilidade da censura prévia, já que a mesma atentaria também contra os valores de liberdade claramente expostos na Carta Magna. Permitir a censura seria uma porta aberta ao autoritarismo, tão frequente na história política do Brasil.

Não se deve esquecer que a Constituição brasileira foi construída num contexto de redemocratização com intensa participação popular, diferente de muitos Países europeus do pós-guerra, de modo que a sua legitimidade é irrefutável e seus valores e princípios não devem ser desprezados. O Estado deve proteger as más ideias ao invés de censurá-las, mesmo que sejam prejudiciais, e assim conduzir políticas que promovam as minorias.

Por óbvio, de outra parte, que o exercício da liberdade de expressão acarreta responsabilidade e ônus, em razão de ofensas. Porém, restringir, de per se, a liberdade de expressão, é algo que não se coaduna com uma Constituição que garante os direitos e as garantias individuais de forma tão contundente. A Constituição é o que é e veda a censura. Não pode, pois, o intérprete, fazer da Carta Magna o que quer, em nome das suas boas intenções e de valores louváveis. Ele é o escravo da Constituição. Ela não pode ser um joguete nas mãos do intérprete. Assim, a liberdade de expressão serve, além de sua função principal, para trazer consequências libertadoras a uma sociedade, através do respeito à autonomia individual e ao desenvolvimento da personalidade.

No momento em que o Estado proíbe um discurso fundamentando que este é prejudicial à comunidade, ele está com toda certeza censurando e violando o ideário de 1988, que almeja uma sociedade aberta, plural e democrática. Não é desprezível, pois, a opinião de Mill, desenvolvida no texto, que somente através da total liberdade de expressão se atinge a verdade, onde todos têm acesso às ideias, más e intolerantes que sejam, pois dessa forma se sustenta um debate público, através do mercado livre de ideias. Os conceitos trazidos por Dworkin são, no mesmo sentido, relevantes, pois o Estado deve possibilitar as variadas formas de opiniões.

O fato de uma opinião ser errada não dá base suficiente para censurá-la, por mais atentatória que seja. Censurar é decair no defeito que se imputa à ideia censurada, o que a Constituição Federal, em nenhum momento, garante. Desse modo, a liberdade de expressão deve implicar responsabilidade, não censura. Não se contesta, pois, a responsabilidade $a$ posteriori, pelas ofensas, mas, sim, repele-se o cerceamento da liberdade de pensamento, ainda que esse pensamento seja "marginal”, "raivoso" e "intolerante”. A Constituição não nos dá o direito de sermos censores e intolerantes com a liberdade de expressão, mas nos permite, $a$ posteriori, responsabilizar aqueles que cometem ilícitos com seus discursos de ódio. 


\section{REFERÊNCIAS}

BARROS, Caroline Maria Costa. A moral como instrumento limitador da liberdade de expressão: apontamentos sobre o exercício (i) legítimo do discurso de ódio. Rio de Janeiro: Lumen Juris, 2015.

BARROS, Caroline Maria Costa. A moral como instrumento limitador da liberdade de expressão: apontamentos sobre o exercício (i) legítimo do discurso de ódio. 1. ed. Rio de Janeiro: Lumen Juris, 2015.

BELLUSCIO, Augusto César. Censura judicial previa a la prensa: posición de la Corte Interamericana de Derechos Humanos. Anuario de Derecho Constitucional Latinoamericano, Montevideo, ano 12, t. II, p. 949-963, 2006.

BRASIL. Constituição (1988). Constituição da República Federativa do Brasil. Brasília, DF: Senado Federal. Disponível em:

http://www.planalto.gov.br/ccivil_03/constituicao/constituicaocompilado.htm. Acessado em: 04 de ago. de 2017.

BRINK, Davi O. Princípios de Millian, liberdade de expressão e discurso de ódio. In: SAMPAIO, José Adércio Leite (Coord.). Liberdade de expressão no século XXI. Belo Horizonte: Del Rey, 2016.

BRUGGER, Wienfried. Proibição ou proteção do discurso de ódio? Algumas observações sobre o direito alemão e o americano. Revista de Direito Público, Brasília, v. 1, n. 15, p. 117-136, jan./mar.2007.

BUTLER, Judith. Excitable Speech. A Politics of the Performative. New York: Routledge, 2000.

CARVALHO, Lucas Borges de. Censura e Liberdade de Expressão no Brasil. Rio de Janeiro: Lumen Juris, 2016.

CAVALCANTE SEGUNDO, Antonio de Holanda. Uma questão de opinião? Liberdade de expressão e seu âmbito protetivo: da livre manifestação do pensamento ao hate speech. Rio de Janeiro: Lumen Juris, 2016.

DWORKIN, Ronald. 0 direito da liberdade: a leitura moral da Constituição norte-americana. Tradução Marcelo Brandão Cipolla. São Paulo: Martins Fontes, 2006.

FARIAS, Edilson. Liberdade de Expressão e Comunicação: teoria e proteção constitucional. São Paulo: Editora Revista dos Tribunais, 2004.

FISS, Owen M. A ironia da liberdade de expressão: Estado, regulação e diversidade na esfera pública. 1. ed. Rio de Janeiro: Renovar, 2005. 
HOLMES, Stephen. Liberal constraints on private power? Reflections on the origins and rationale of acess regulation. In: LICHTENBERG, Judith. Democracy and mass media. Nova York: Cambridge University Press. 1995.

JABUR, Gilberto Haddad. Liberdade de pensamento e direito à vida privada: conflitos entre direitos da personalidade. São Paulo: Editora Revista dos Tribunais, 2000.

KANT apud FARIAS, Edilson. Liberdade de Expressão e Comunicação: teoria e proteção constitucional. São Paulo: Editora Revista dos Tribunais, 2004.

MENDES, Gilmar. A Jurisdição constitucional no Brasil e seu significado para a liberdade e a igualdade. Disponível em:

http://www.stf.jus.br/arquivo/cms/noticiaartigodiscurso/anexo/munster_port.pdf. Acessado em 3 ago. 2017.

MEYER-PFLUG, Samantha Ribeiro. Liberdade de Expressão e discurso do ódio. São Paulo: Editora Revista dos Tribunais, 2009.

MILL, John Stuart. Sobre a liberdade. Tradução Alberto da Rocha Barros. 2. ed. Rio de Janeiro: Vozes, 1991.

OMMATI, José Emílio Medauar. Liberdade de Expressão e discurso de ódio na Constituição de 1988. 3. ed. Rio de Janeiro: Lumen Juris, 2016.

PINTO, Indiara Liz Fazolo. Liberdade de expressão, Lei de Imprensa e discurso de ódio - Da restrição como violação à limitação como proteção. A\&C - R. de Dir. Administrativo \& Constitucional | Belo Horizonte, ano 13, n. 53, p. 195-229, jul./set. 2013.

SAGÜES, Nestor Pedro. Censura judicial previa a la prensa: posición de la Corte Interamericana de Derechos Humanos. Anuario de Derecho Constitucional Latinoamericano, Montevideo, ano 12, t. II, p. 965-977, 2006.

SARLET, Ingo Wolfgang; MARINONI, Luiz Guilherme. MITIDIEIRO, Daniel. Curso de Direito Constitucional. 4. ed. ampl. São Paulo: Saraiva, 2015.

SARMENTO, Daniel. LIVRES E IGUAIS: Estudos de Direito Constitucional. Rio de Janeiro: Lumen Juris, 2006.

SAUNDERS, Kevin W. Degradation: What the history of obscenity tells us about hate speech. Nova lorque: New York University, 2011.

SEDLER, Robert A. Um ensaio sobre a liberdade de expressão: Os Estados Unidos versus o resto do mundo. In: SAMPAIO, José Adércio Leite (Coord.). Liberdade de expressão no século XXI. Belo Horizonte: Del Rey, 2016. 
SUNSTEIN, Cass R. Democracy and the problem of free speech. Nova lorque: The Free Press, 1995.

TOURIÑO, Alejandro. El derecho al olvido y a la personalidade en internet. Madrid: Catarata, 2014.

WEINSTEIN, James. An overview of american free speech doctrine and its application to extreme speech. In: HARE, Ivan; WEINSTEIN, James. Extreme speech and democracy. Oxford: Oxford University, 2009.

\section{COMO FAZER REFERÊNCIA AO ARTIGO (ABNT):}

WEDY, Miguel Tedesco; HORBACH, Lenon Oliveira. Uma abordagem comparada acerca do discurso de ódio entre Brasil e Estados Unidos. Revista Eletrônica do Curso de Direito da UFSM, Santa Maria, RS, v. 14, n. 2, e37204, maio./ago. 2019. ISSN 1981-3694. DOI: http://dx.doi.org/10.5902/1981369430692. Disponível em: https://periodicos.ufsm.br/revistadireito/article/view/30692 Acesso em: dia mês. ano.

Direitos autorais 2019 Revista Eletrônica do Curso de Direito da UFSM

Editores responsáveis: Rafael Santos de Oliveira e Angela Araujo da Silveira Espindola

Este obra está licenciado com uma Licença Creative Commons Atribuição-NãoComercial-SemDerivações 4.0 Internacional.

\section{SOBRE OS AUTORES}

\section{MIGUEL TEDESCO WEDY}

Possui graduação em Ciências Jurídicas e Sociais pela Pontifícia Universidade Católica do Rio Grande do Sul (1999) e mestrado em Ciências Criminais pela Pontifícia Universidade Católica do Rio Grande do Sul (2002). Atualmente é professor do Programa de Pós-Graduação em Direito da Unisinos (Mestrado e Doutorado) e Decano da Escola de Direito da Unisinos. É doutor em Direito pela Faculdade de Direito da Universidade de Coimbra, com título revalidado pela Unisinos em 2013, conforme apostila de reconhecimento. Tem experiência na área de Direito, com ênfase em Direito Processual Penal e Direito Penal, atuando principalmente nos seguintes temas: direito, penal, prisão, processo penal e princípio. Professor da Escola Superior da Magistratura do Rio Grande do Sul, advogado - Escritório de Advocacia Wedy Advogados.

\section{LENON OLIVEIRA HORBACH}

Mestrando em Direito Público pela Universidade do Vale do Rio dos Sinos - UNISINOS. Pós-graduando em Direito Civil pela LFG. Formado em Ciências Jurídicas e sociais - Direito pela PUCRS, e formado no curso técnico em eletrotécnica pela Fundação Escola Técnica Liberato Salzano Vieira da Cunha. Realizei monitoria na disciplina de Filosofia e Ética Geral, pela Faculdade de Filosofia da PUCRS. Realizei dois anos de pesquisa em Iniciação Científica, o primeiro fomentado pela Fundação de Amparo a Pesquisa do Estado do Rio Grande do Sul - FAPERGS, tendo objeto de estudo a bioética. 0 segundo ano foi fomentado pelo CNPQ - Conselho Nacional de Desenvolvimento Científico e Tecnológico, tendo como objeto de estudo direitos fundamentais. Estudo língua inglesa há 3 anos pela Influx English School, e a língua Francesa há 1 ano pela NELE Núcleo de Ensino de Linguas e Extensão - UFRGS. 